\title{
REAPPRAISAL OF GREGUSS' FOSSIL WOOD TYPES AND FIGURED SPECIMENS FROM THE CENOZOIC OF HUNGARY: OVERVIEW, CORRECTED GEOLOGY AND SYSTEMATICAL NOTES
}

\author{
JAKUB SAKALA ${ }^{1, *}$, ILDIKÓ SELMECZI², LILLA HABLY³ $^{3}$ \\ ${ }^{1}$ Institute of Geology and Palaeontology, Faculty of Science, Charles University, Albertov 6, 12843 Prague 2, the Czech Republic; e-mail: \\ rade@natur.cuni.cz. \\ ${ }^{2}$ Mining and Geological Survey of Hungary, Stefánia út 14, 1443 Budapest, Hungary; e-mail: selmeczi.ildiko@mbfsz.gov.hu. \\ ${ }^{3}$ Hungarian Natural History Museum, Botanical Department, PO Box 137, 1431, Budapest, Hungary; e-mail: hably.lilla@nhmus.hu. \\ * corresponding author
}

Sakala, J., Selmeczi, I., Hably, L. (2018): Reappraisal of Greguss' fossil wood types and figured specimens from the Cenozoic of Hungary: overview, corrected geology and systematical notes. - Fossil Imprint, 74(1-2): 101-114, Praha. ISSN 2533-4050 (print), ISSN 2533-4069 (on-line).

\begin{abstract}
Prof. Pál Greguss $(* 1889, \uparrow 1984)$ was a leading figure in European (palaeo)xylotomy. His collection of types and figured specimens from the Cenozoic of Hungary published in the two monographs (Fossil gymnosperm woods in Hungary from the Permian to the Pliocene and Tertiary angiosperm woods in Hungary), now stored in the Palaeobotanical Collection of the Botanical Department in the Hungarian Natural History Museum in Budapest, is of great value. Many types were considered lost, but the present reappraisal, conducted by the first author during several visits to Budapest between 2009 and 2016, uncovered 18 types, 35 figured specimens and 1 additional specimen, 54 items in total. In the text, all specimens are briefly presented with their systematical attribution, information on their numbers, localities and their corrected geological age. The text is completed by two photo-plates and one summary table.
\end{abstract}

Key words: fossil conifer wood, fossil angiosperm wood, Pál Greguss, Hungarian Natural History Museum in Budapest, Cenozoic, Hungary, types, figured specimens

Received: February 18, 2018 | Accepted: April 17, 2018 | Issued: August 31, 2018

\section{Introduction}

Prof. Pál Greguss $(* 1889, \dagger 1984)$, botany professor at the University of Szeged, was active in several diverse fields of botany, but he gained international recognition as a xylotomist. He studied at the University of Budapest and Charles University in Prague. In 1919, he defended his doctoral thesis at the University of Budapest. He worked in Szeged from 1928 until his death. His most important scientific publications were those in the field of xylotomy, e.g. "Xylotomische Bestimmung der heute lebenden Gymnospermen", "Holzanatomie der europäischen Laubhölzer und Sträucher", or "Xylotomy of the living Cycads, with a description of their leaves and epidermis" (Greguss 1955a, 1959, 1968), which are all frequently cited monographs (more on Prof. Greguss' life in Horváth 1975, Gulyás 1989, and his bibliography in Gulyás 1985).

He compiled wood samples from countless arboreal species of modern gymnosperms and angiosperms in order to have modern comparative material for use in the anatomical identification of fossil wood remains. He made permanent slides of all samples resulting in one of the largest xylotomy collections in Europe. The collection comprises at least 3,800 slides of European arboreal broadleaved species and gymnosperms of the world. An outstanding part of the collection is that concerning cycads. The fossil material, which represents mainly the Hungarian Tertiary but in part also Mesozoic and Palaeozoic sites, includes 167 inventoried samples and the total number of thin sections exceeds 500 .

The collection had been stored in Greguss' work room at the University of Szeged for decades but in 2007, a couple of decades after his death, the collection was transferred to the Hungarian Natural History Museum due to reorganization and lack of space. The invaluable Greguss collection is now stored in the Palaeobotanical Collection of the Botanical Department in the Hungarian Natural History Museum and its reappraisal was conducted by the first author during several visits to Budapest between 2009 and 2016. The present contribution represents the main results relative to the types and figured specimens from the Cenozoic of Hungary published by Greguss $(1967,1969)$. 


\section{Geological setting}

Considering Greguss' original age indications for the different fossiliferous localities we present here, we faced two problems:

Firstly, the original names and definitions of geological stages do not correspond to current ones. The main discrepancy is in the Miocene subdivision and this cannot be understood without a short explanation. Generally, before the 1970s, authors in Hungary and in the neighbouring countries (i.e. in the former Czechoslovakia and Austria) correlated the Hungarian Neogene successions with SWEuropean stages, and therefore, the names Aquitanian, Burdigalian, Helvetian and Tortonian became accepted. The names Sarmatian and Pannonian were introduced for those successions which could not have been correlated with the SW-European situation due to the isolation of the Paratethys. However, it should be noted that the "Tortonian" used formerly in Hungary was not coeval with the Tortonian stratotype; it was older based on the biostratigraphic data (Báldi 1968, Piller et al. 2007). The correlation problems between the Mediterranean and the Paratethys resulted in the establishment of regional chronostratigraphic scales in the 1970s, published in the "Chronostratigraphie und Neostratotypen” volumes (e.g. Steininger and Seneš 1971, Báldi and Seneš 1975, Papp et al. 1978). For our contribution, we present here a simplified correlation scheme, where the stages on the left are Greguss' original ones (in italics, see Tab. 1: column labelled "Original age") and the stages on the right are the Central Paratethys versions, which roughly correspond to those according to Greguss' interpretation, from younger to older:

Pannonian $=$ late Miocene + Pliocene

Sarmatian $=$ Sarmatian

Tortonian $=$ Badenian

Helvetian $=$ Ottnangian + Karpatian

Burdigalian $=$ Eggenburgian

The recent correlation between Central Paratethys and standard stages can be found e.g., in Piller et al. (2007). It is worth mentioning that in Greguss' classification, Sarmatian belongs to the Miocene (it represents the youngest Age of this Epoch), whereas - from his point of view - the Pannonian Age corresponds only to the Pliocene.

Secondly, in the last 50 years geology has greatly progressed and many age attributions need to be corrected. Therefore, one of us (IS) undertook a detailed geological reinvestigation in order to revise the age of the fossils. These results are mainly based on recent geological maps (showing the distribution of geological formations on the surface) with explanatory books produced for these maps and monographs (e.g. Hámor 1985, Selmeczi and Kordos 2008, Gyalog 2013, Kercsmár et al. 2015) and also on inspection of borehole successions which were studied in the Archives of the Mining and Geological Survey of Hungary. All data are summarised in Table 1 (referred to as "Revised age").

\section{Material and methods}

This reappraisal of Greguss' fossil wood types and figured specimens is mainly based on his two monographs (Greguss
1967, 1969) and follows the modern systematics expressed by a linear classification presented by Christenhusz et al. (2011) and the Angiosperm Phylogeny Group (2016) for "gymnosperms" and angiosperms respectively. The higher level classification frame is adopted from Chase and Reveal (2009). The last numeral in the new numbers, under which the specimens are recorded in the palaeobotanical collections of the Hungarian Natural History Museum in Budapest, corresponds to the number of thin slides of that specimen; the specimens themselves are missing. The slides are described as follows: "tr" for transverse section, "tg" for tangential longitudinal section and "rd" for radial longitudinal section, e.g. " $2 * \operatorname{tr}+\operatorname{tg} / \mathrm{rd}$ " means there are 3 slides, two of them are transverse and one is oblique, cut somewhere between tangential and radial longitudinal sections. All data including localities and their original and corrected ages are summarised in Table 1.

\section{Systematic palaeobotany}

\section{Subclass Pinidae Cronquist, Takhtajan et Zimmermann, 1966 (= conifers)}

Family Pinaceae LindLey, 1836

Genus Laricioxylon Greguss, 1967

1) Laricioxylon nogradense Greguss, 1967

Pl. 1, Figs 1, 2

Material. Holotype HNHM-PBO 2008.201.2. (= 2 slides: $\operatorname{tr}+\mathrm{rd})$.

D e s c ription. See Greguss (1967: 97, pl. LXXXVI, figs $1-6$, legend p. 136).

$\mathrm{N}$ ote s. These re-discovered slides can be considered as the holotype of Laricioxylon nogradense, which is the type species of the fossil genus Laricioxylon (for discussion see Philippe et al. 1999). The tangential longitudinal section, however, is missing. Concerning the affinity to Larix, we did not observe the typical abrupt transition from earlywood to latewood (see in IAWA Committee 2004: feature 42), which is probably obscured by wood deformation (Pl. 1, Fig. 1). Resin canals seem to be traumatic and present in latewood in tangential bands (P1. 1, Fig. 1, arrows). In the radial section, we observed neither bordered pits in radial tracheid walls nor cross-field pits, but the bordered pits in ray tracheids (Pl. 1, Fig. 2, arrow), which appear to have wide apertures and rounded pit borders (see in IAWA Committee 2004: fig. 45), are rather typical for Larix.

\section{Genus Pinuxylon Gothan, 1905}

\section{2) Pinuxylon haploxyloides Greguss, 1967}

M t teria l. Holotype HNHM-PBO 2008.160.3. (= 3 slides: $\operatorname{tr}+\operatorname{tg}+\mathrm{rd})$.

Description. See Greguss (1967: 99, pl. LXXX, figs $1-7$, legend p. 135). 


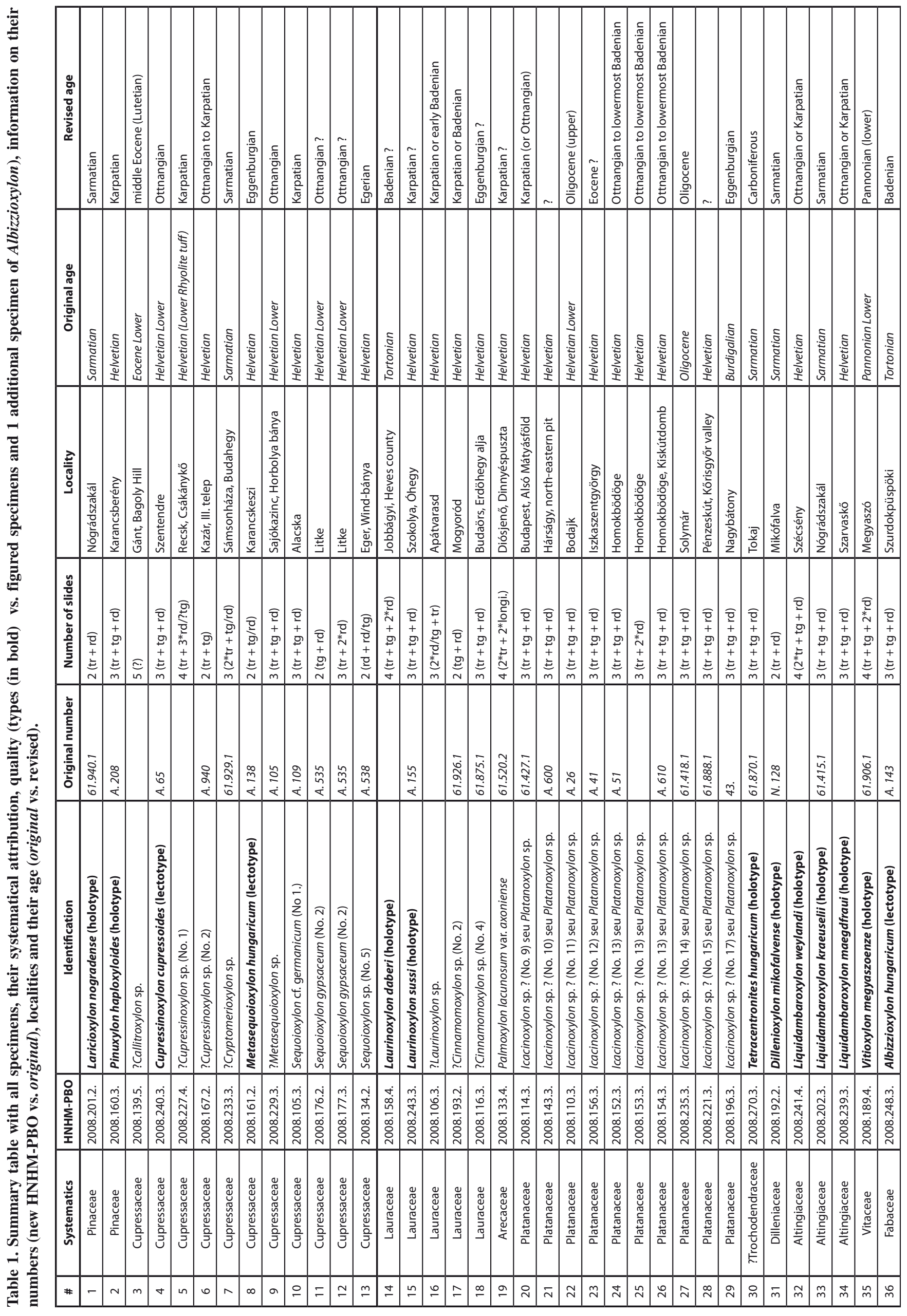



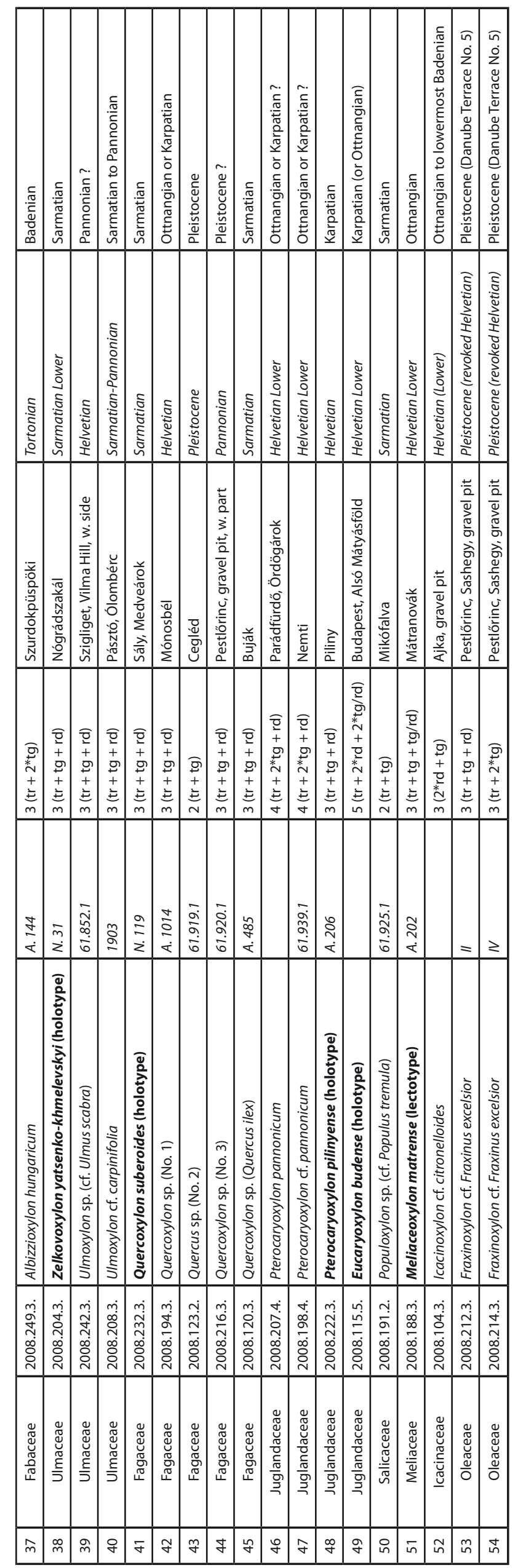

Family Cupressaceae Gray, 1821

Genus [Callitroxylon Greguss, 1967] (not validly published)

\section{3) ?Callitroxylon sp.}

Material. Figured specimen HNHM-PBO 2008.139.5. (= 5 slides: impossible to determine sections).

Des cription. See Greguss (1967: 55, pl. XLVIIIa, figs 1-9, legend p. 127).

Notes. The thin slides are extremely problematic with small very dark organic fragments. Moreover, as stated by Philippe et al. (1999), Callitroxylon Greguss “... is not associated with any species name, and thus is not validly published". According to Farr and Zijlstra (Index Nominum Genericorum (Plantarum) - http://botany.si.edu/ ing/; checked on February 13, 2018), validly published is Callitroxylon HarTig, 1848.

\section{Genus Cupressinoxylon GöPPERT, 1850 nom. cons.}

4) Cupressinoxylon cupressoides Greguss, 1967 (later homonym of Cupressinoxylon cupressoides KRÄUSEL, 1919)

Pl. 1, Figs 3, 4

Material. Lectotype defined here HNHM-PBO 2008.240.3. (= 3 slides: $\operatorname{tr}+\operatorname{tg}+\mathrm{rd})$.

Description. See Greguss (1967: 61, pl. LIV, figs $1-6$, legend p. 128).

Notes. The similar wood anatomy, but different original number from that used by Greguss (1967: 62), i.e. A. 538 vs. A. 65 , show that the holotype is missing and we need to define here this fossil as a lectotype of Cupressinoxylon cupressoides Greguss. However, $C$. cupressoides P.GREGuss is considered as a later homonym of Cupressinoxylon cupressoides KRÄUSEL (Kräusel 1920: 429) and must be considered as "illegitimate". Finally, any affinity to Cupressus itself remains questionable as the fossil has biseriate bordered pits with bars of Sanio (P1. 1, Fig. 3) and taxodioid cross-field pits (P1. 1, Fig. 4, arrows), both typical of Taxodioxylon (e.g. Teodoridis and Sakala 2008).

\section{5) ?Cupressinoxylon sp. (No. 1)}

Material. Figured specimen HNHM-PBO 2008.227.4. (= 4 slides: $\operatorname{tr}+3 *$ rd/?tg).

D e s c ription. See Greguss (1967: 62, pl. LXXVIII, figs 1-6, legend p. 134).

Notes. It is a poorly preserved dark wood with latewood preserved as a compact dark material.

\section{6) ?Cupressinoxylon sp. (No. 2)}

Material. Figured specimen HNHM-PBO 2008.167.2. (=2 slides: $\operatorname{tr}+\operatorname{tg})$.

D e s c r i p t i o n. See Greguss (1967: 63, pl. LIV, figs 7, 8 , legend p. 128).

N o t e s. Again, this is a very poorly preserved slide. 


\section{Genus [Cryptomerioxylon Greguss, 1967] (not validly published)}

7) ?Cryptomerioxylon sp.

Material. Figured specimen HNHM-PBO 2008.233.3. (= 3 slides: $2 * \operatorname{tr}+\operatorname{tg} / \mathrm{rd})$.

D e s c ription. See Greguss (1967: 66, pl. LIII, figs 1-3, legend p. 128).

$\mathrm{N}$ ot e s. It is a very poorly preserved fossil wood and its relationship to ?Cryptomerioxylon sp. described by Greguss (1967: 66) remains questionable. As Philippe et al. (1999) already stated, Cryptomerioxylon GREGUSS “... is not associated with any species name, and thus is not validly published”.

\section{Genus Metasequoioxylon Greguss, 1967}

8) Metasequoioxylon hungaricum Greguss, 1967

$$
\text { P1. 1, Figs 5, } 6
$$

Material. Lectotype defined here HNHM-PBO 2008.161.2. (=2 slides: $\operatorname{tr}+\operatorname{tg} / \mathrm{rd})$.

D e s c ription. See Greguss (1967: 69, pl. LV, figs 3, 4, 8-12, legend p. 129).

Note s. As stated by Philippe et al. (1999), no type was indicated for Metasequoioxylon GREGUSS. Therefore, we define here these slides as the only fossil present from the original material as a lectotype of Metasequoioxylon hungaricum GREGUSS and the fossil genus Metasequoioxylon GrEGUSS. Similarly to Greguss (1967), we observed smooth and thin transverse end walls of axial parenchyma (Pl. 1, Fig. 5). Concerning the radial tracheid pitting, it is mainly opposite, but there is sometimes a weak tendency toward an alternate (or rather "araucaroid") arrangement (Pl. 1, Fig. 6). Generally, the existence of Metasequoia in the continental European Tertiary remains problematic and its wood is recognized today as a species of the fossil genus Taxodioxylon HARTIG, 1848: T. vanderburghii DolezyCH, 2011 (for more details see Dolezych and Estrada 2012).

\section{9) ?Metasequoioxylon sp.}

Material. Figured specimen HNHM-PBO 2008.229.3. (= 3 slides: $\operatorname{tr}+\operatorname{tg}+\mathrm{rd})$.

De s cription. See Greguss (1967: 71, pl. LVI, figs 1-9, legend p. 129).

N o t e s. This is a very well preserved "taxodioid" wood.

\section{Genus [Sequoioxylon Greguss, 1955b] (not validly published)}

\section{0) Sequoioxylon cf. germanicum (No 1.) Greguss, 1957}

Material. Figured specimen HNHM-PBO 2008.105.3. (= 3 slides: $\operatorname{tr}+\operatorname{tg}+\mathrm{rd})$.

D e s c ription. See Greguss (1967: 76, pl. LV, figs 1, 2, 5-7, legend p. 129).

Notes. Sequoioxylon Greguss (Greguss 1955b) is not validly published (for more details see Philippe et al. 1999 and Farr and Zijlstra in Index Nominum Genericorum (Plantarum) - http://botany.si.edu/ing/).
11) Sequoioxylon gypsaceum (GöPPERT, 1842) GREGUSS, 1967 (No. 2) (not validly published combination)

Material. Figured specimen HNHM-PBO 2008.176.2. (=2 slides: $\operatorname{tg}+\mathrm{rd})$.

12) Sequoioxylon gypsaceum (GöPPERT, 1842) GREGUSS, 1967 (No. 2) (not validly published combination)

Material. Figured specimen HNHM-PBO 2008.177.3. (=3 slides: $\operatorname{tr}+2 *$ rd $)$.

D e s c ription. See Greguss (1967: 79, pl. LXIII, figs 1-9, legend p. 131).

Notes. The two specimens (nos 11 and 12 in present paper) have the same original number (A. 535) so we think the slides come from the same wood, figured in Greguss (1967: 79, pl. LXIII). Contrary to his observation, we did not observe the type of transverse end walls seen in axial parenchyma which represents an important feature.

\section{3) Sequoioxylon sp. (No. 5)}

Material. Figured specimen HNHM-PBO 2008.134.2. (=2 slides: $\mathrm{rd}+\mathrm{rd} / \mathrm{tg})$.

D e s c r i p ti o n. See Greguss (1967: 90, pl. LIV, fig. 9, legend p. 128).

Subclass Magnoliidae Novák ex TAKHTAJAn, 1967 (= angiosperms)

Family Lauraceae Jussieu, 1879

Genus Laurinoxylon FeLIx, 1883

Genus Laurinoxylon was emended by Dupéron, DupéronLaudoueneix, Sakala and De Franceschi (2009)

14) Laurinoxylon daberi Greguss, 1969 Pl. 1, Figs 7-9

Materia l. Holotype HNHM-PBO 2008.158.4. (= 4 slides: $\operatorname{tr}+\operatorname{tg}+2 *$ rd)

D e s c r i p ti o n. See Greguss (1969: 34, pl. XVII, figs 1-11, legend p. 134).

Notes. As Greguss (1969) noticed, there is a large amount of diffuse axial parenchyma, seen in cross-section as white dots within a brown matrix substance (P1. 1, Fig. 7), idioblasts are both in rays (Pl. 1, Fig. 9, arrows) and axial parenchyma (P1. 1, Fig. 8., upper arrow) with the former not as pronounced. Following the new classification by Mantzouka et al. (2016), this species belongs to Laurinoxylon Type 2a. There are also numerous crystals, mainly associated with axial parenchyma (Pl. 1, Fig. 8, lower arrow).

\section{5) Laurinoxylon sussi Greguss, 1969}

P1. 1, Fig. 10

Materia l. Holotype HNHM-PBO 2008.243.3. (= 3 slides: $\operatorname{tr}+\operatorname{tg}+\mathrm{rd}$ ).

D e s c ri p ti o n. See Greguss (1969: 35, pl. XVIII, figs 1-7, legend p. 135).

Notes. The wood is diffuse-porous with vessels solitary, in radial multiples or clusters with vasicentric 
parenchyma and 2-3-seriate heterocellular rays with conspicuous marginal oil/mucilage cells. These idioblasts are very prominent and seem to be located in the margins of rays only (Pl. 1, Fig. 10), therefore this is a Laurinoxylon Type 1 sensu Mantzouka et al. (2016).

\section{6) ?Laurinoxylon sp.}

Material. Figured specimen HNHM-PBO 2008.106.3. (=3 slides: $2 * \mathrm{rd} / \mathrm{tg}+\mathrm{tr})$.

De s c ription. See Greguss (1969: 36, pl. XIX, figs 1-9, legend p. 135).

\section{Genus [Cinnamomoxylon Greguss, 1969] (not validly published)}

\section{7) ?Cinnamomoxylon sp. (No. 2)}

Material. Figured specimen HNHM-PBO 2008.193.2. (= 2 slides: $\operatorname{tg}+\mathrm{rd})$.

D e s c r i p t i o n. See Greguss (1969: 37, pl. XVIII, figs 8,9 , legend p. 135).

Notes. There are 2-3-seriate rays with oil cells, and numerous tyloses.

\section{8) ?Cinnamomoxylon sp. (No. 4)} Pl. 1, Figs 11, 12

Material. Figured specimen HNHM-PBO 2008.116.3. (= 3 slides: $\operatorname{tr}+\operatorname{tg}+\mathrm{rd})$.

De s c ription. See Greguss (1969: 39, pl. XXI, figs 7-9, legend p. 135).

Notes. Regular tangential bands of parenchyma in cross-section (Pl. 1, Fig. 11) as well as long series of crystalliferous parenchyma in longitudinal sections (Pl. 1, Fig. 12) suggest more likely some Juglandaceae rather than Lauraceae (see below). Moreover, typical idioblasts were not clearly seen. For the purpose of this overview, however, we follow Greguss' original classification.

\section{Family Arecaceae Berchtold et J.Presl, 1820 \\ Genus Palmoxylon Schenk, 1882}

\section{9) Palmoxylon lacunosum var. axoniense WATELET}

Material. Figured specimen HNHM-PBO 2008.133.4. (= 4 slides: $2 * \operatorname{tr}+2 *$ longitudinal).

Description. See Greguss (1969: 21, pl. VI, figs $1-9$, legend p. 132).

\section{Family Platanaceae T.Lestiboudois, 1826}

Icacinoxylon sp. ? (Nos 8-16) seu Platanoxylon sp. Pl. 1, Figs 13, 14

20) Icacinoxylon sp. ? (No. 9) seu Platanoxylon sp.

Material. Figured specimen HNHM-PBO 2008.114.3. (= 3 slides: $\operatorname{tr}+\operatorname{tg}+\mathrm{rd})$.

D e s c r i p ti o n. See Greguss (1969: 70, pl. LIX, figs 4, 5, legend p. 144).
21) Icacinoxylon sp. ? (No. 10) seu Platanoxylon sp.

Material. Figured specimen HNHM-PBO 2008.143.3. (= 3 slides: $\operatorname{tr}+\operatorname{tg}+\mathrm{rd})$.

D e s c r i p t i o n. See Greguss (1969: 70, pl. LIX, fig. 6, legend p. 144).

\section{2) Icacinoxylon sp. ? (No. 11) seu Platanoxylon sp.}

Material. Figured specimen HNHM-PBO 2008.110.3. (= 3 slides: $\operatorname{tr}+\operatorname{tg}+\mathrm{rd})$.

D e s c ri p ti o n. See Greguss (1969: 70, pl. LX, figs 1, 2, legend p. 144).

\section{3) Icacinoxylon sp. ? (No. 12) seu Platanoxylon sp.}

Material. Figured specimen HNHM-PBO 2008.156.3. (= 3 slides: $\operatorname{tr}+\operatorname{tg}+\mathrm{rd})$.

Des cription. see Greguss (1969: 70, pl. LX, figs 3-6, legend p. 144).

24) Icacinoxylon sp. ? (No. 13) seu Platanoxylon sp.

Material. Figured specimen HNHM-PBO 2008.152.3. ( $=3$ slides: $\operatorname{tr}+\operatorname{tg}+\mathrm{rd})$.

25) Icacinoxylon sp. ? (No. 13) seu Platanoxylon sp.

Material. Figured specimen HNHM-PBO 2008.153.3. (= 3 slides: $\operatorname{tr}+2 *$ rd $)$.

26) Icacinoxylon sp. ? (No. 13) seu Platanoxylon sp.

Material. Figured specimen HNHM-PBO 2008.154.3. (= 3 slides: $\operatorname{tr}+\operatorname{tg}+\mathrm{rd})$.

Des cription. See Greguss (1969: 70, pl. LX, figs 7-9, legend p. 144).

27) Icacinoxylon sp. ? (No. 14) seu Platanoxylon sp.

Material. Figured specimen HNHM-PBO 2008.235.3. ( $=3$ slides: $\operatorname{tr}+\operatorname{tg}+\mathrm{rd})$.

D e s c r i p t i o n. See Greguss (1969: 70, pl. LIX, figs 7, 8 , legend p. 144).

\section{8) Icacinoxylon sp. ? (No. 15) seu Platanoxylon sp.}

Material. Figured specimen HNHM-PBO 2008.221.3. (= 3 slides: $\operatorname{tr}+\operatorname{tg}+\mathrm{rd})$.

Des cription. See Greguss (1969: 70, pl. LIX, figs $1-3$, legend p. 144).

\section{9) Icacinoxylon sp. ? (No. 17) seu Platanoxylon sp.}

Material. Figured specimen HNHM-PBO 2008.196.3. (= 3 slides: $\operatorname{tr}+\operatorname{tg}+\mathrm{rd})$.

Des cription. See Greguss (1969: 71, pl. LVI, figs 7-9, legend p. 143, pl. LXI, figs 1-9, legend p. 145).

Notes. All woods are very similar, they all have a "platanoid" aspect with chiefly solitary vessels with scalariform perforation plates and large homocellular rays (P1. 1, Figs 13, 14). Unfortunately, due to the fact that the 
contents of vessels are strongly recrystallized, it is not possible to see any possible spirals. We observed clear ones only in "Icacinoxylon sp. ? (No. 17) seu Platanoxylon sp.". Generally, their presence is important in delimiting the fossil genus Spiroplatanoxylon Süss, 2007 (e.g. Sakala et al. 2010, Továrková et al. 2011). We regrouped here all “Icacinoxylon sp. ? seu Platanoxylon sp." woods under Platanaceae, but the Tertiary "platanoid" woods require a more general revision, which is beyond the scope of the present review (Sakala and Gryc in prep.). All three specimens from Homokbödöge are placed here under "Icacinoxylon sp. ? (No. 13) seu Platanoxylon sp." and one of the three specimens (HNHMPBO 2008.153.3.) is represented by older slides without any number.

\section{Family ? Trochodendraceae EICHLER, 1865}

Genus Tetracentronites MATHIESEN, 1932

30) Tetracentronites hungaricum GREGUSS, 1964 Pl. 1, Figs 15, 16

Materia 1. Holotype HNHM-PBO 2008.270.3. (= 3 slides: $\operatorname{tr}+\operatorname{tg}+\mathrm{rd})$.

Description. See Greguss (1969: 24 (only mentioned but without description, more in Greguss 1964), pl. VII, figs 1, 2, pl. VIII, figs 3-10, pl. IX, figs 11-20, legend p. 132).

Notes. The holotype of this homoxylous wood was rediscovered in Budapest by $\mathrm{M}$. Philippe. It has up to 3-seriate rays (Pl. 1, Fig. 15) and radial tracheid walls with scalariform to dense circular bordered pits (Pl. 1, Fig. 16). However, as reported by Philippe et al. (2010), this "angiosperm" wood is actually a reworked Carboniferous wood of the Pitys type (determination by J. Galtier), so very probably represents an extinct pteridosperm and not a angiosperm. However, for the purpose of this overview and its clarity, we place it here following Greguss' original classification. Concerning the geological setting, the locality (Tokaj) was listed by Greguss as Sarmatian as the volcanics of that age occurred there. On the other hand, Palaeozoic rocks have not been recorded on the surface in the immediate vicinity. As a result, the Carboniferous age of the fossil can either be explained by the existence of Palaeozoic xenoliths (in Sarmatian volcanics), which may have contained the plant remains, or by a redeposition of Carboniferous sediments from a significant distance (e.g. surroundings of Vel'ká Tŕňa in Slovakia, further north).

Family Dilleniaceae SALISBURy, 1807

Genus Dillenioxylon Greguss, 1969

31) Dillenioxylon mikofalvense Greguss, 1969 P1. 2, Figs 1, 2

Materia l. Holotype HNHM-PBO 2008.192.2. (= 2 slides: $\operatorname{tr}+\mathrm{rd})$.

Description. See Greguss (1969: 26, pl. XI, figs 1-10, legend p. 133).

Notes. The wood is diffuse-porous with rays of 2 types: uniseriate and wide (Pl. 2, Fig. 1) and mostly solitary vessels with opposite to scalariform intervessel pits (which are similar to vessel-ray pits), scalariform perforation plates (P1. 2, Fig. 2) and tyloses.

\section{Family Altingiaceae LindLAY, 1846}

Genus Liquidambaroxylon FeLIx, 1884

32) Liquidambaroxylon weylandi GREGuSs, 1969 Pl. 2, Fig. 3

Materia l. Holotype HNHM-PBO 2008.241.4. (= 4 slides: $2 * \operatorname{tr}+\operatorname{tg}+\mathrm{rd}$ ).

D e s c r i p t i o n. See Greguss (1969: 42, pl. XXIV, figs 1-9, legend p. 136).

N o t e s. There are opposite vessel-ray pits, 20-30 bars in scalariform perforation plates (Pl. 2, Fig. 3, left), and numerous bubble-like inclusions (granules) in rays, seen in radial section (Pl. 2, Fig. 3, arrows).

\section{3) Liquidambaroxylon kraeuselii Greguss, 1969}

$$
\text { Pl. 2, Fig. } 4
$$

Materia l. Holotype HNHM-PBO 2008.202.3. (= 3 slides: $\operatorname{tr}+\operatorname{tg}+\mathrm{rd})$.

D e s c r i p t i o n. See Greguss (1969: 44, pl. XXVI, figs 1-9, legend p. 136).

N o t e s. Similarly to Greguss (1969), we observed the scalariform perforation plates with only about 10 bars (which is a rather low number for Liquidambar; for comparison see Sakala and Privé-Gill 2004), and heterocellular rays with long uniseriate extremities. Moreover, there are rich crystalliferous contents in chambered axial parenchyma (P1. 2, Fig. 4, arrow) and possibly also disjunctive ray parenchyma cell walls.

\section{4) Liquidambaroxylon maegdefraui Greguss, 1969}

Pl. 2, Figs 5, 6

Materia l. Holotype HNHM-PBO 2008.239.3. (= 3 slides: $\operatorname{tr}+\operatorname{tg}+\mathrm{rd}$ ).

Description. See Greguss (1969: 45, pl. XXVII, figs 1-9, legend p. 137).

N o t e s. This is a well-preserved wood with an excellent radial section showing scalariform perforation plates with almost 30 bars (Pl. 2, Fig. 5, right arrow, Pl. 2, Fig. 6). The rays are uniseriate to biseriate (Pl. 2, Fig. 5, left arrow), so different from the other species of Liquidambaroxylon. The original inventory number (No. 61.932.1.) quoted by Greguss (1969: 46) was not observed on the slides, but we consider the specimen as an original holotype.

\section{Family Vitaceae Jussieu, 1789}

Genus Vitioxylon Greguss, 1969

\section{5) Vitioxylon megyaszoenze Greguss, 1969} Pl. 2, Figs 7, 8

Materia l. Holotype HNHM-PBO 2008.189.4. (= 4 slides: $\operatorname{tr}+\operatorname{tg}+2 * r d)$. 
D e s c ription. See Greguss (1969: 58, pl. XXXVIII, figs 1-9, legend p. 139).

N o te s. The wood is diffuse-porous (Pl. 2, Fig. 7) with big (Pl. 2, Fig. 8, left arrow) and small (Pl. 2, Fig. 8, right arrow) vessels intermixed and extremely high rays. Such a wood type, i.e., with two vessel size classes throughout the wood, is typical of lianas (see Type 5 in Baas et al. 2004).

Family Fabaceae LindLAY, 1836

\section{Genus [Albizzioxylon Greguss, 1969] (illegitimate)}

36) Albizzioxylon hungaricum Greguss, 1969 P1. 2, Fig. 9

Material. Lectotype defined here HNHM-PBO 2008.248.3. (= 3 slides: $\operatorname{tr}+\operatorname{tg}+\mathrm{rd})$.

\section{7) Albizzioxylon hungaricum Greguss, 1969 Pl. 2, Fig. 10}

Material. Additional specimen HNHM-PBO 2008.249.3. (=3 slides: $\operatorname{tr}+2 * \operatorname{tg})$.

D e s c r i p t i o n. See Greguss (1969: 50, pl. XXIX, figs 1-9, pl. XXX, figs 10-18, legend p. 137).

Notes. The wood is diffuse-porous with vessels solitary or in radial multiples (Pl. 2, Fig. 9) with tyloses (or fragmented gum deposits) and very dense small alternate pits, parenchyma aliform to confluent sometimes crystalliferous and 1-5-seriate homocellular rays (Pl. 2, Fig. 10). Because the holotype A. 142 is missing, we define here the specimen HNHM-PBO 2008.248.3., with all three sections present, as the lectotype. However, it seems that Greguss, when proposing a new fossil genus, did not realise that the generic name Albizzioxylon already existed; the name was proposed already twice before his proposal (Albizzioxylon RAMANUJAM, 1960 and Albizzioxylon A.A.NIKIT. 1935; see Farr and Zijlstra in Index Nominum Genericorum (Plantarum)). As a consequence, Albizzioxylon GrEGUSS is a later homonym and must be considered as "illegitimate".

\section{Family Ulmaceae Mirbel, 1815}

Genus Zelkovoxylon Greguss, 1969

\section{8) Zelkovoxylon yatsenko-khmelevskyi GREGUSS, 1969}

$$
\text { Pl. 2, Fig. } 11
$$

Materia l. Holotype HNHM-PBO 2008.204.3. (= 3 slides: $\operatorname{tr}+\operatorname{tg}+\mathrm{rd})$.

Description. See Greguss (1969: 83, pl. LXXVI, figs 1-9, legend p. 148).

Note s. This is a well-preserved wood with crystals in the axial parenchyma along the rays (Pl. 2, Fig. 11, arrow) and spirals and tyloses in the vessels. Concerning the wood of Ulmaceae in general, a good overview was recently produced by Wheeler and Manchester (2007).

\section{Genus Ulmoxylon KAISER, 1879}

39) Ulmoxylon sp. (cf. Ulmus scabra Miller, 1768) P1. 2, Fig. 12
Material. Figured specimen HNHM-PBO 2008.242.3. (= 3 slides: $\operatorname{tr}+\operatorname{tg}+\mathrm{rd})$.

D e s c r i p t i o n . See Greguss (1969: 86, pl. LXXV, figs 6-10, legend p. 148).

$\mathrm{N}$ o te s. There are homocellular rays, and clear spirals in vascular tracheids visible in the radial section (Pl. 2, Fig. 12 , arrows).

\section{0) Ulmoxylon ef. Ulmus carpinifolia GLEDITSCH, 1773}

Material. Figured specimen HNHM-PBO 2008.208.3. (= 3 slides: $\operatorname{tr}+\operatorname{tg}+$ rd).

D e s c r i p t i o n . Ssee Greguss (1969: 86, pl. LXXVIII, figs $1-4$, legend p. 148).

$\mathrm{N}$ o t e s . There are homocellular rays up to 8 cells in width.

Family Fagaceae DuMorTIER, 1828

Genus Quercoxylon KRÄUSEL, 1939 (Quercus L., 1753)

41) Quercoxylon suberoides GREguss, 1969

Materia l. Holotype HNHM-PBO 2008.232.3. (= 3 slides: $\operatorname{tr}+\operatorname{tg}+\mathrm{rd})$.

D e s c ri pti o n. See Greguss (1969: 73, pl. LXVI, figs $1-3,6,6 a$ and 9 , legend p. 146).

$\mathrm{N}$ ot e s. Oxalate crystals are in both axial parenchyma and uniseriate rays, there is also the characteristic vessel-ray pitting.

\section{2) Quercoxylon sp. (No. 1)}

Material. Figured specimen HNHM-PBO 2008.194.3. (= 3 slides: $\operatorname{tr}+\operatorname{tg}+\mathrm{rd})$.

Description. See Greguss (1969: 73, pl. LXVII, figs $1-3$, legend p. 146).

$\mathrm{N}$ o t e s. The transverse and tangential sections are good quality.

\section{3) Quercus sp. (No. 2)}

Material. Figured specimen HNHM-PBO 2008.123.2. (=2 slides: $\operatorname{tr}+\operatorname{tg})$.

Description. See Greguss (1969: 74, pl. LXVII, figs 4-6, legend p. 146).

Notes. This is a well preserved wood.

\section{4) Quercoxylon sp. (No. 3)}

Material. Figured specimen HNHM-PBO 2008.216.3. (= 3 slides: $\operatorname{tr}+\operatorname{tg}+\mathrm{rd})$.

D e s c ri p t i o n. See Greguss (1969: 74, pl. LXVI, figs 4-8, legend p. 146).

Notes. There is "alsóhelvéti" (Lower Helvetian) written on the slide, which is in contradiction with the original Pannonian age indicated by Greguss (1969: 74). The permineralised wood contains numerous black dots which are apparently linked to its preservation. 
45) Quercoxylon sp. (Quercus ilex)

M a t e r i a l. Figured specimen HNHM-PBO 2008.120.3. (=3 slides: $\operatorname{tr}+\operatorname{tg}+\mathrm{rd})$.

Description. See Greguss (1969: 76, only mentioned in the text).

Family Juglandaceae DC. ex Perleb, 1818

Genus Pterocaryoxylon Müller-Stoll et Mädel, 1960

46) Pterocaryoxylon pannonicum MüLLER-STOLL et MäDEL, 1960

Material. Figured specimen HNHM-PBO 2008.207.4. ( $=4$ slides: $\operatorname{tr}+2 * \operatorname{tg}+\mathrm{rd})$.

D e s c ri p tio n. See Greguss (1969: 76, pl. LXIX, figs 1-9, legend p. 146).

Notes. The wood is diffuse-porous with solitary vessels or in radial multiples of $2-3$. There are mostly 2-seriate heterocellular rays and banded axial parenchyma full of oxalate crystals.

\section{7) Pterocaryoxylon cf. pannonicum MüLleR-STOLL} et MäDEL, 1960

M a t e r i a l. Figured specimen HNHM-PBO 2008.198.4. (= 4 slides: $\operatorname{tr}+2 * \operatorname{tg}+\mathrm{rd})$.

Des cription. See Greguss (1969: 77, pl. LXX, figs 1-4, legend p. 147).

Note s. This is a diffuse-porous wood with tangential bands of parenchyma, mostly uniseriate rays and numerous oxalate crystals in the axial parenchyma.

48) Pterocaryoxylon pilinyense Greguss, 1969 Pl. 2, Fig. 13

Materia l. Holotype HNHM-PBO 2008.222.3. (= 3 slides: $\operatorname{tr}+\operatorname{tg}+\mathrm{rd}$ ).

D e s c r i p t i o n. See Greguss (1969: 77, pl. LXXI, figs 1-9, legend p. 147).

Notes. The vessels are solitary or in multiples of 3 or more with dense intervessel pitting, axial parenchyma is present as banded, in 1-3-cell wide tangential bands, and paratracheal vasicentric. Crystals are in chambered axial parenchyma, clearly seen in the radial section, with about 8 chambers per strand ( $\mathrm{Pl}$. 2, Fig. 13). This type is known today as Rhysocaryoxylon pilinyense (GrEGUSS, 1969) DupÉron, 1988 (see in Sakala and Gryc 2011).

\section{Genus Eucaryoxylon Müller-Stoll et Mädel, 1960}

49) Eucaryoxylon budense GREGUSS, 1969

$$
\text { P1. 2, Fig. } 14
$$

Materia 1. Holotype HNHM-PBO 2008.115.5. (= 5 slides: $\operatorname{tr}+2 * \mathrm{rd}+2 * \operatorname{tg} / \mathrm{rd}$ ).

Description. See Greguss (1969: 79, pl. LXXII, figs $1,3-9$, legend p. 147).
Notes. We did not observe any ring-porosity, as mentioned by Greguss (1969: 79), but only diffuse-porosity (Pl. 2, Fig. 14). However, based on the overall similarity of the description in the protologue, we consider the specimen as the holotype of Eucaryoxylon budense Greguss, 1969.

Family Salicaceae Mirbel, 1815

Genus Populoxylon MäDel-Angeliewa, 1968

50) Populoxylon sp. (cf. Populus tremula L., 1753)

Material. Figured specimen HNHM-PBO 2008.191.2. (= 2 slides: $\operatorname{tr}+\operatorname{tg})$.

D e s c r i p t i o n. See Greguss (1969: 83, pl. LXXV, figs 1-5, legend p. 148).

$\mathrm{N}$ o te s. This is a well preserved semi-ring porous wood with radially grouped vessels with simple perforation plates and alternate polygonal intervessel pits, and only uniseriate rays. Because of the lack of a radial section, it is not possible to confirm whether the rays are homocellular, similar to Populus L., or hererocellular, similar to Salix L. (compare Sakala et al. 2006). On the slide, there is a lettering "helvéti".

Family Meliaceae Jussieu, 1789

Genus Meliaceoxylon Greguss, 1969

51) Meliaceoxylon matrense Greguss, 1969 Pl. 2, Figs 15, 16

Material. Lectotype defined here HNHM-PBO 2008.188.3. (= 3 slides: $\operatorname{tr}+\operatorname{tg}+\operatorname{tg} / \mathrm{rd})$.

Description. See Greguss (1969: 89, pl. LXXX, figs 1-9, legend p. 149).

Notes. This is a diffuse-porous wood with vessels in radial multiples, intercellular canals of traumatic origin, closely spaced in tangential bands (P1. 2, Fig. 15), axial parenchyma diffuse to diffuse-in-aggregates, and paratracheal and 2-3-seriate heterocellular rays. We also observed an unusual and relatively big structure that we interpret as an isolated axial canal, probably also of traumatic origin (Pl. 2, Fig. 16). Concerning the (in)validity of the fossil genus Meliaceoxylon GREguss (see Farr and Zijlstra in Index Nominum Genericorum ), there are two type specimens indicated by Greguss (1969: 90), i.e. Nos 201 and 202. Our reinvestigation discovered that specimen No. 201 was missing, so we define here the specimen HNHM-PBO 2008.188.3. (= A. 202) as the lectotype.

\section{Family Icacinaceae Miers, 1851}

Genus Icacinoxylon SHILkINA, 1956

\section{2) Icacinoxylon cf. citronelloides SHILKINA, 1956}

Material. Figured specimen HNHM-PBO 2008.104.3. (=3 slides: $2 * \mathrm{rd}+\operatorname{tg})$.

De s c ription. See Greguss (1969: 61, pl. XLI, figs 1-9, legend p. 140). 


\section{Family Oleaceae Hoffmannsegg et Link, 1809}

Genus Fraxinoxylon E.Hofmann, 1934

53) Fraxinoxylon cf. Fraxinus excelsior L., 1753

Material. Figured specimen HNHM-PBO 2008.212.3. (= 3 slides: $\operatorname{tr}+\operatorname{tg}+\mathrm{rd})$.

\section{4) Fraxinoxylon cf. Fraxinus excelsior L., 1753}

Material. Figured specimen HNHM-PBO 2008.214.3. (=3 slides: $\operatorname{tr}+2 * \operatorname{tg})$.

D e s c r i p t i o n . See Greguss (1969: 99, pl. XCI, fig. 4, pl. XCIII, figs 1-4, legend p. 151).

N o t e s. Both woods show prominent tangential bands of parenchyma in late wood and vasicentric to aliform (or even confluent) paratracheal parenchyma. We believe they both represent the slides from the same tree, so we range them under "Fraxinoxylon cf. Fraxinus excelsior L.". The transverse section illustrated by fig. XCIII/1 represents the cross-section of specimen HNHM-PBO 2008.214.3.

\section{Conclusions}

Prof. Pál Greguss $(* 1889, \uparrow 1984)$ was a leading figure in European (palaeo)xylotomy. His collection of the types and figured specimens from the Cenozoic of Hungary published in two monographs (Greguss 1967, 1969), now stored in the Palaeobotanical Collection of the Botanical Department in the Hungarian Natural History Museum in Budapest, is of great value and interest for any (palaeo)xylotomist. In fact, many types were considered inaccessible or lost (compare with Philippe et al. 1999), but the present reappraisal, conducted by the first author during his visits to Budapest between 2009 and 2016, brought to light 18 types, 35 figured specimens and 1 additional specimen, 54 items in total. In the text, we briefly presented all specimens, their botanical classification, information on their numbers, localities and their revised geological age. Therefore, the ultimate aim of the present paper was to make a complete inventory which would serve as a solid base for future systematical studies, mainly with respect to selected angiosperm families such as Platanaceae, Ulmaceae and Juglandaceae.

\section{Acknowledgements}

First, we thank the two reviewers: Baas and M. Philippe for their thorough reviews, which significantly improved the manuscript. We also thank L. Fodor for his comments on geology and J. Wagner for a fine editorial work. This work is dedicated to Prof. Zlatko Kvaček on the occasion of his $80^{\text {th }}$ birthday with our best wishes and many thanks. Our research was supported by the grants PROGRES Q45 and Hungarian Scientific Research Fund (NKFIH K108664).

\section{References}

Angiosperm Phylogeny Group (2016): An update of the Angiosperm Phylogeny Group classification for the orders and families of flowering plants: APG IV. - Botanical Journal of the Linnean Society, 181: 1-20.

https://doi.org/10.1111/boj.12385

Baas, P., Ewers, F. W., Davis, S. D., Wheeler, E. A. (2004): Evolution of xylem physiology. - In: Hemsley, A. R., Poole, I. (eds), The evolution of plant physiology: From whole plants to ecosystems. The Linnean Society of London \& Elsevier Academic Press, London, pp. 273-295. https://doi.org/10.1016/B978-012339552-8/50016-0

Báldi, T. (1968): Az európai neogén emeletek helyzetéről [About the current status of the Neogene stages in Europe]. - Bulletin of the Hungarian Geological Society (= Földtani Közlöny), 98(2): 285-289. (in Hungarian)

Báldi, T., Seneš, J. (1975): Chronostratigraphie und Neostratotypen. Miozän der Zentralen Paratethys, Bd. 5: OM Egerien. Die Egerer, Pouzdřaner, Puchkirchener Schichtengruppe und die Bretkaer Formation. - Slovenská Akadémia Vied, Bratislava, 577 pp.

Chase, M. W., Reveal, J. L. (2009): A phylogenetic classification of the land plants to accompany APG III. - Botanical Journal of the Linnean Society, 161: 122-127. https://doi.org/10.1111/j.1095-8339.2009.01002.x

Christenhusz, M. J. M., Reveal, J. L., Farjon, A., Gardner, M. F., Mill, R. R., Chase, M. W. (2011): A new classification and linear sequence of extant gymnosperms. Phytotaxa, 19: 55-70. https://doi.org/10.11646/phytotaxa.19.1.3

Dolezych, M., Estrada, S. (2012): A fossil wood of Taxodioxylon vanderburghii DolEzych in Palaeogene sediments of Ellesmere Island (Nunavut, Canada). - Zeitschrift der Deutschen Gesellschaft für Geowissenschaften, 163: 283-292. https://doi.org/10.1127/1860-1804/2012/0163-0283

Dupéron, J., Dupéron-Laudoueneix, M., Sakala, J., De Franceschi, D. (2008): Ulminium diluviale Unger : historique de la découverte et nouvelle étude (Ulminium diluviale Unger: Historical data on the discovery and new study). - Annales de Paléontologie, 94: 1-12. https://doi.org/10.1016/j.annpal.2007.12.003

Greguss, P. (1955a): Xylotomische Bestimmung der heute lebenden Gymnospermen. - Akadémiai Kiadó, Budapest, $308 \mathrm{pp}$

Greguss, P. (1955b): Oznaczenie dolno-mioceńskiego pnia drzewa z Turowa nad Nysą Łużycką [Description of fossil wood from Turow near Nysą Lużycka]. - Acta Geologica Polonica, 5(2): 273-275. (in Polish)

Greguss, P. (1959): Holzanatomie der europäischen Laubhölzer und Sträucher. - Akadémiai Kiadó, Budapest, $330 \mathrm{pp}$.

Greguss, P. (1964): A new homoxylous tree in the Miocene flora of Hungary, Tetracentronites hungaricum nov. sp. Palaeobotanist, 12: 277-281.

Greguss, P. (1967): Fossil gymnosperm woods in Hungary from the Permian to the Pliocene. - Akadémiai Kiadó, Budapest, $136 \mathrm{pp}$.

Greguss, P. (1968): Xylotomy of the living Cycads, with a description of their leaves and epidermis. - Akadémiai Kiadó, Budapest, 260 pp.

Greguss, P. (1969): Tertiary angiosperm woods in Hungary. - Akadémiai Kiadó, Budapest, 151 pp. 
Gulyás, S. (1985): Bibliography publications of Prof. Dr. Pál Greguss 1909-1982. - Acta Biologica Szegediensis, 31: 207-214.

Gulyás, S. (1989): Pál Greguss life and activity (In memóriám Professor Greguss). - Acta Biologica Szegediensis, 35: 37-38.

Gyalog, L. (ed.) (2013): Magyarország földtani térképe. Geological map of Hungary 1: 500 000. - Geological and Geophysical Institute of Hungary.

Hámor, G. (1985): A Nógrád-Cserhát kutatási terület földtani viszonyai. Geology of the Nógrád-Cserhát area. Geologica Hungarica, Series Geologica, 22: 215- 307.

Horváth, I. (1975): Prof. Pál Greguss is 85 years old. - Acta Biologica Szegediensis, 21: 3-8.

IAWA Committee (2004): IAWA list of microscopic features for softwood identification. - IAWA Journal, 25: 1-70. https://doi.org/10.1163/22941932-90000349

Kercsmár, Z. (ed.), Budai, T., Csillag, G., Selmeczi, I., Sztanó, O. (2015): Surface geology of Hungary. Explanatory notes to the geological map of Hungary (1: 500 000). - Geological and Geophysical Institute of Hungary, Budapest, $66 \mathrm{p}$.

Kräusel, R. (1920): Nachträge zur Tertiärflora Schlesiens. II. Braunkohlenhölzer. - Jahrbuch der Königlich Preussischen geologischen Landesanstalt und Bergakademie zu Berlin, 39(1): 418-460.

Mantzouka, D., Karakitsios, V., Sakala, J., Wheeler, E. A. (2016): Using idioblasts to group Laurinoxylon species: case study from the Oligo-Miocene of Europe. - IAWA Journal, 37: 459-488. https://doi.org/10.1163/22941932-20160147

Papp, A., Cicha, I., Seneš, J., Steininger, F. (1978): Chronostratigraphie und Neostratotypen. Miozän der Zentralen Paratethys, Bd. 6: M4: Badenien (Moravien, Wielicien, Kosovien). - Slovenská Akadémia Vied, Bratislava, 594 p.

Philippe, M., Cuny, G., Bashforth, A. (2010): Ecpagloxylon mathiesenii gen. nov. et sp. nov., a Jurassic wood from Greenland with several primitive angiosperm features. Plant Systematics and Evolution, 287: 153-165. https://doi.org/10.1007/s00606-010-0308-z

Philippe, M., Zijlstra, G., Barbacka, M. (1999): Greguss's morphogenera of homoxylous fossil woods: a taxonomic and nomenclatural review. - Taxon, 48: 667-676. https://doi.org/10.2307/1223638

Piller, W. E., Harzhauser, M., Mandic, O. (2007): Miocene Central Paratethys stratigraphy - current status and future directions. - Stratigraphy, 4: 151-168.

Sakala, J., Gryc, V. (2011): A new species of Rhysocaryoxylon (Juglandaceae) from the Lower Eocene Fur Formation of Mors island (northwest Jutland, Denmark). - Bulletin of the Geological Society of Denmark, 59: 45-49.

Sakala, J., Košt’ák, M., Mazuch, M., Štěpánková, J. (2006): Dendrological characteristics of subrecent fossil plant remains from the Uzon Caldera in Kamchatka (eastern Russia). - Acta Universitatis Carolinae, Geologica, 47: 125-128.

Sakala, J., Privé-Gill, C. (2004): Oligocene angiosperm woods from northwestern Bohemia, Czech Republic. IAWA Journal, 25: 369-380. https://doi.org/10.1163/22941932-90000372
Sakala, J., Rapprich, V., Pécskay, Z. (2010): Fossil angiosperm wood and its host deposits from the periphery of a dominantly effusive ancient volcano (Doupovské hory Volcanic Complex, Oligocene-Lower Miocene, Czech Republic): systematics, volcanology, geochronology and taphonomy. - Bulletin of Geosciences, 85: 617-629. https://doi.org/10.3140/bull.geosci.1196

Selmeczi, I., Kordos, L. (2008): Csatka Formation. - In: Budai, T., Fodor, L. (eds), Geology of the Vértes Hills. Explanatory Book to the Geological Map of the Vértes Hills (1: 50 000). Regional map series of Hungary. Geological Institute of Hungary, Budapest, pp. 258-260.

Steininger, F., Seneš, J. (1971): Chronostratigraphie und Neostratotypen. Miozän der Zentralen Paratethys, Bd. 2: M1 Eggenburgien. Die Eggenburger Schichtengruppe und ihr Stratotypus. - Slovenská Akadémia Vied, Bratislava, $827 \mathrm{pp}$.

Teodoridis, V., Sakala, J. (2008): Early Miocene conifer macrofossils from the Most Basin (Czech Republic). Neues Jahrbuch für Geologie und Paläontologie, Abhandlungen, 250: 287-312. https://doi.org/10.1127/0077-7749/2008/0250-0287

Továrková, I., Gryc, V., Sakala, J. (2011): First anatomically characterized wood from the Tertiary of Moravia: Spiroplatanoxylon from the area of Austerlitz (Southern Moravia, Czech Republic). - Acta Universitatis Agriculturae et Silviculturae Mendelianae Brunensis, 59: 367-372. https://doi.org/10.11118/actaun201159060367

Wheeler, E. A., Manchester, S. R. (2007): Review of the wood anatomy of extant Ulmaceae as context for new reports of late Eocene Ulmus woods. - Bulletin of Geosciences, 82: 329-342. https://doi.org/10.3140/bull.geosci.2007.04.329 


\section{Explanations of plates}

\section{PLATE 1}

Laricioxylon nogradense GREGUSS (holotype HNHM-PBO 2008.201.2.)

1. Transition from earlywood to latewood obscured by wood deformation, traumatic resin canals in tangential bands in latewood (arrows), tr.

2. Cross-field with bordered pits in ray tracheid (arrow), rd.

Cupressinoxylon cupressoides GREGUSs (lectotype HNHMPBO 2008.240.3.)

3. Biseriate bordered pits with bars of Sanio in radial tracheid walls, rd.

4. Taxodioid cross-field pits (arrows), rd.

Metasequoioxylon hungaricum GREGUss (lectotype HNHMPBO 2008.161.2.)

5. Smooth and thin transverse end walls of axial parenchyma, tg.

6. Opposite radial tracheid pitting with weak tendency to "araucaroid" arrangement, rd.

Laurinoxylon daberi GREGUSS (holotype HNHM-PBO 2008.158.4.)

7. General view in transverse section with tylosed vessels and diffuse axial parenchyma, tr.

8. Idioblast (upper arrow) and crystal (lower arrow) in axial parenchyma), tg.

9. Idioblasts in rays (arrows), rd.

Laurinoxylon sussi GreGuss (holotype HNHM-PBO 2008.243.3.)

10. Idioblasts in rays (arrows), rd.

?Cinnamomoxylon sp. (No. 4) (figured specimen HNHMPBO 2008.116.3.)

11. Vessels and regular tangential bands of parenchyma, tr.

12. Chambered crystalliferous parenchyma, rd.

Icacinoxylon sp. ? (No. 14) seu Platanoxylon sp. (figured specimen HNHM-PBO 2008.235.3.)

13. "Platanoid" diffuse-porous wood with solitary vessels and large rays, tr.

Icacinoxylon sp. ? (No. 12) seu Platanoxylon sp. (figured specimen HNHM-PBO 2008.156.3.)

14. General "platanoid" aspect with large rays, tg.

Tetracentronites hungaricum GREGUSS (holotype HNHMPBO 2008.270.3.)

15. Homoxylous wood with up to 3 -seriate rays, tr.

16. Radial tracheid walls with scalariform to dense circular bordered pits, rd.

\section{PLATE 2}

Dillenioxylon mikofalvense GreGuss (holotype HNHMPBO 2008.192.2.)

1. Diffuse porous wood with 2 types of rays: uniseriate and wide, tr.

2. Scalariform perforation plate with 20 bars, rd.

Liquidambaroxylon weylandi GREGUSS (holotype HNHMPBO 2008.241.4.)

3. Scalariform perforation plate with 28 bars (left) and bubble-like inclusions in rays (arrows), $\mathrm{rd}$.
Liquidambaroxylon kraeuselii GREGUSs (holotype HNHMPBO 2008.202.3.)

4. Crystalliferous axial parenchyma (arrows), tg.

Liquidambaroxylon maegdefraui GREGUss (holotype HNHM-PBO 2008.239.3.)

5. 1-2-seriate rays (left arrow) and scalariform perforation plate with 27 bars (right arrow), tg.

6. Two scalariform perforation plates with 27 bars, rd.

Vitioxylon megyaszoenze GREGUSs (holotype HNHM-PBO 2008.189.4.)

7. Diffuse-porous wood with large and small vessels intermixed throughout the wood, tr.

8. Detail of big (left arrow) and small (right arrow) vessels side by side, tr.

Albizzioxylon hungaricum GREGUSs (lectotype HNHM-PBO 2008.248.3.)

9. Diffuse-porous with vessels solitary or in radial multiples and aliform to confluent parenchyma, tr.

Albizzioxylon hungaricum GREGUSS (additional specimen HNHM-PBO 2008.249.3.)

10. 1-5-seriate homocellular rays and vessels with tyloses or ?fragmented gum deposits (arrow), tg.

Zelkovoxylon yatsenko-khmelevskyi GREGUSs (holotype HNHM-PBO 2008.204.3.)

11. Crystals in axial parenchyma along the rays (arrow), tg. Ulmoxylon sp. (cf. Ulmus scabra MiLl.) (figured specimen HNHM-PBO 2008.242.3.)

12. Spirals in vascular tracheids (arrows), $\mathrm{rd}$.

Pterocaryoxylon pilinyense Greguss (holotype HNHMPBO 2008.222.3.)

13. Chambered crystals in axial parenchyma (with 8 chambers), tg.

Eucaryoxylon budense GREGUSS (holotype HNHM-PBO 2008.115.5.)

14. Diffuse-porous wood with axial parenchyma in regular tangential bands, tr.

Meliaceoxylon matrense GrEGUSS (lectotype HNHM-PBO 2008.188.3.)

15. Intercellular canals (arrow) arranged in tangential bands, tr.

16. Putative big isolated axial canal (?cavity), tr.

$\operatorname{tr}$ - transverse section, $\operatorname{tg}$ - tangential longitudinal section, rd - radial longitudinal section

scale bar is the same for all figures and represents:

$250 \mu \mathrm{m}$ in Figs 1, 13, 14, 15 for Plate 1 and in Figs 1, 7, 9, 14 for Plate 2

$100 \mu \mathrm{m}$ in Figs 7, 11 for Plate 1 and in Figs 10, 15, 16 for Plate 2

$50 \mu \mathrm{m}$ in in Figs 5, 9, 10, 12 for Plate 1 and in Figs 4, 5, 6, $8,11,12$ for Plate 2

$25 \mu \mathrm{m}$ in in Figs 2, 3, 4, 6, 8, 16 for Plate 1 and in Figs 2, 3, 13 for Plate 2 
PLATE 1
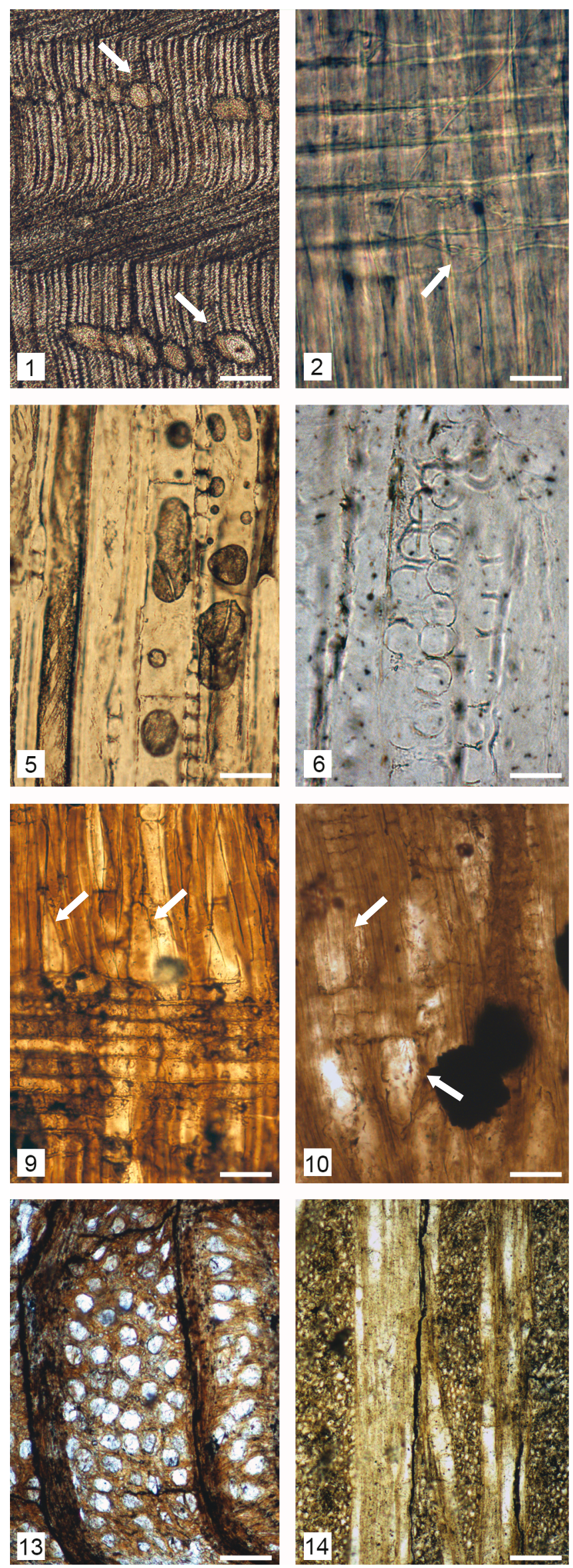
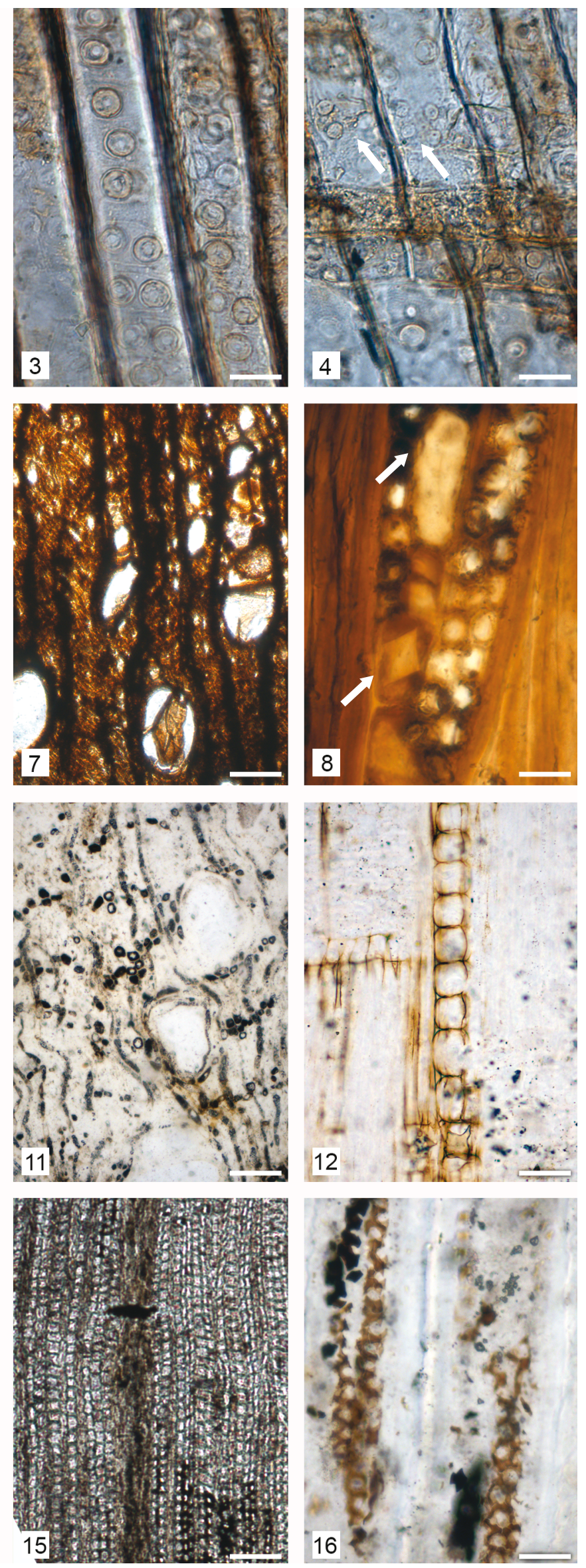
PLATE 2
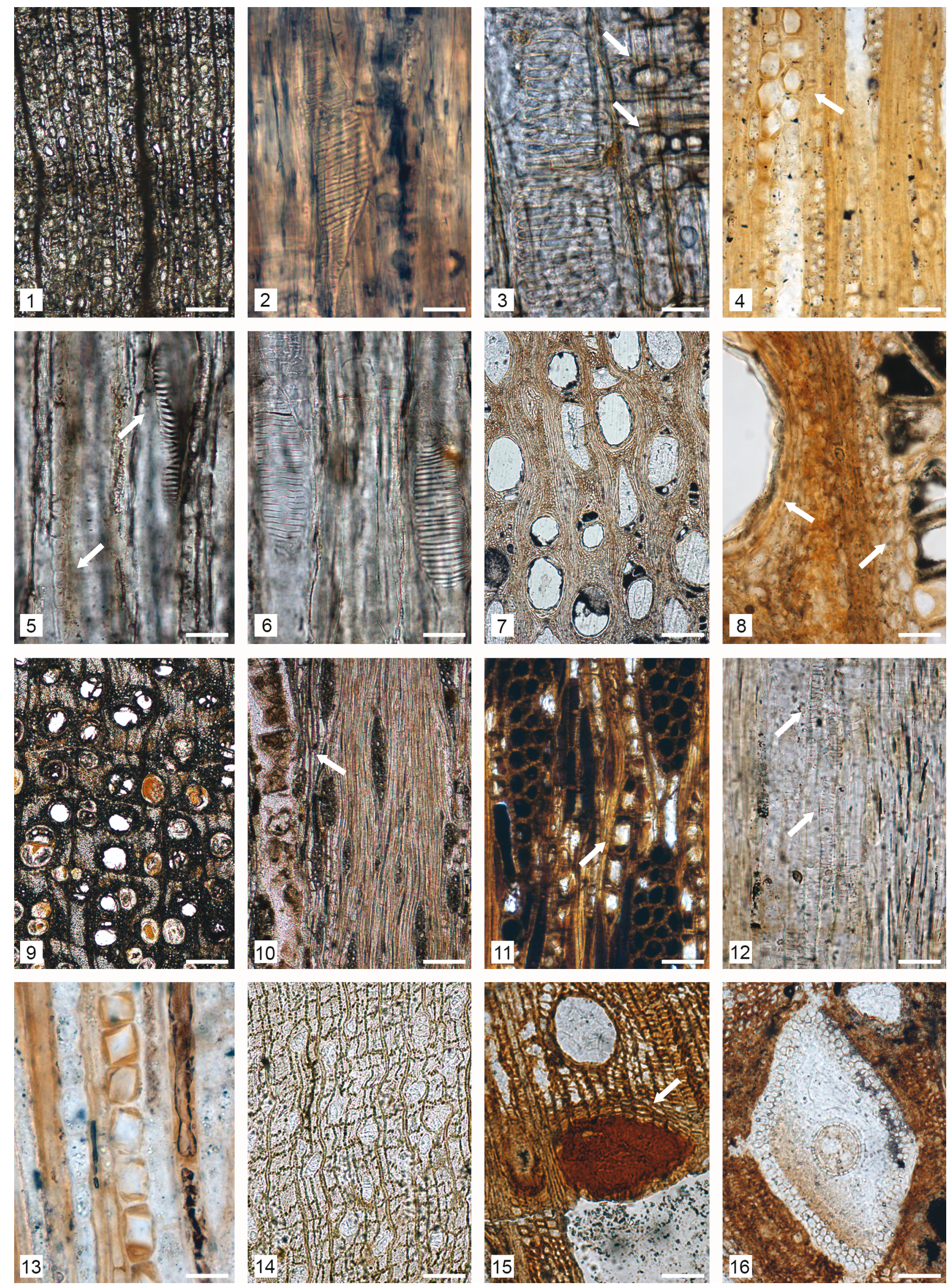